\title{
C-X-C Chemokine Receptor Type 3
}

National Cancer Institute

\section{Source}

National Cancer Institute. C-X-C Chemokine Receptor Type 3. NCI Thesaurus. Code C26227.

C-X-C chemokine receptor type 3 (368 aa, $\sim 41 \mathrm{kDa}$ ) is encoded by the human CXCR3 gene. This protein plays a role in cell proliferation, cell survival and angiogenesis. 